\title{
DETERMINAN KEPATUHAN WAJIB PAJAK MUSLIM UNTUK MEMBAYARKAN PAJAK
}

\author{
Agung Andriono ${ }^{1}$, Amir Hidayatulloh ${ }^{2}$ \\ ${ }^{1,2}$ Program Studi Akuntansi Universitas Ahmad Dahlan \\ Email: amir.hidayatulloh@act.uad.ac.id
}

\begin{abstract}
The purpose of this study was to analyze the influence of zakat knowledge as a deducation from taxable income and income level on Muslim taxpayer compliance. The population in this study are taxpayers in Bantul Regency. The sampling technique in this study uses purposive sampling with criteria (1) Muslim taxpayers in Bantul Regency, (2) taxpayers who have a taxpayer identification number, and (3) taxpayers who run free business or jobs. Data collection techniques in this study used a questionnaire distributed directly to respondents who met the criteria. The questionnaire collected in this study amounted to 36 questionnaires. Data analysis technique in this study used multiple linear regression analysis with help of SPSS tools. This study found that Muslim taxpayer compliance was influenced by income level. Meanwhile, the knowledge of zakat a deducation from taxable income does not affect Muslim taxpayer compliance.
\end{abstract}

Keywords: Zakat Knowledge, Taxable Income, Income Level, Taxpayer Compliance

\begin{abstract}
ABSTRAK
Tujuan Penelitian ini adalah untuk menganalisis pengaruh pengetahuan zakat sebagai pengurang penghasilan kena pajak dan tingkat pendapatan terhadap kepatuhan wajib pajak Muslim. Populasi dalam penelitian ini adalah wajib pajak yang berada di Kabupaten Bantul. Teknik pengambilan sampel dalam penelitian ini menggunakan purposive sampling dengan kriteria (1) wajib pajak Muslim di kabupaten Bantul, (2) wajib pajak yang memiliki nomor pokok wajib pajak, serta (3) wajib pajak yang menjalankan usaha atau pekerjaan bebas. Teknik pengumpulan data dalam penelitian ini menggunakan kuesioner yang disebarkan secara langsung kepada responden yang memenuhi kriteria. Kuesioner yang terkumpul dalam penelitian ini berjumlah 36 kuesioner. Teknik analisis data dalam penelitian ini menggunakan analisis regresi linear berganda dengan bantuan alat SPSS. Penelitian ini memperoleh hasil bahwa kepatuhan wajib pajak Muslim dipengaruhi oleh tingkat pendapatan. Sedangkan, pengetahuan zakat sebagai pengurang penghasilan kena pajak tidak berpengaruh terhadap kepatuhan wajib pajak Muslim
\end{abstract}

Kata kunci: Pengetahuan Zakat, Penghasilan Kena Pajak, Tingkat Pendapatan, Kepatuhan Wajib Pajak 


\section{PENDAHULUAN}

Zakat merupakan harta yang wajib dibayarkan oleh setiap Muslim yang telah memenuhi syarat untuk disalurkan kepada orang-orang yang berhak menerimanya. Subjek zakat adalah orang Islam yang telah memenuhi nishab atas harta yang dimiliki dengan persyaratan seperti Muslim sudah baligh, merdeka dan berakal (tidak gila), milik yang sempurna (legal secara hukum), serta cukup nishabnya. Sedangkan, objek zakat merupakan kekayaan atau penghasilan yang diperoleh kaum muslimin yang sudah mencapai nishabnya, sehingga kaum muslimin tersebut berkewajiban mengeluarkan sebagaian dari harta yang dimiliki dan diberikannya kepada orang yang berhak menerimanya sesuai dengan syariat Islam (Yusuf \& Ismail, 2017).

Menurut (Undang-undang Nomor 28 Tahun 2007), pajak didefinisikan sebagai kontribusi wajib dari warga Negara kepada Negara yang pemungutannya dapat dipaksakan. Hal ini karena pemungutan pajak didasarkan pada undangundang. Selain itu, wajib pajak tidak mendapatkan jasa timbal balik secara langsung dari pembayaran pajak. Penerimaan pajak dari warga Negara digunakan oleh Pemerintah untuk memenuhi kebutuhan Negara dan kemakmuran rakyat yang sebesar-besarnya. Lebih lanjut Resmi (2014); Mardiasmo, (2016) menyatakan bahwa pajak memiliki dua fungsi yaitu fungsi anggaran dan fungsi pengatur. Pajak berfungsi sebagai anggaran berarti pajak digunakan sebagai salah satu komponen penerimaan Negara. Sedangkan, pajak berfungsi sebagai pengatur berarti bahwa pajak digunakan untuk mengatur kehidupan sosial dan ekonomi.

Pajak dan zakat tidak dikenakan oleh semua masyarakat Indonesia. Zakat dikenakan atas muslimin yang memiliki kekayaan atau penghasilan yang sudah mencapai nishabnya (Yusuf \& Ismail, 2017). Sedangkan, pajak dikenakan atas orang yang penghasilannya melebihi penghasilan tidak kena pajak. Sehingga, individu tidak akan dikenakan pajak penghasilan jika penghasilan individu tersebut kurang dari atau sama dengan lima puluh empat juta rupiah per tahun (Peraturan Menteri Keuangan Nomor 101 Tahun 2016).

Menurut Muktiyanto \& Hendrian (2008), menyatakan bahwa sebagaian besar pembayar zakat juga merupakan pembayar pajak. Namun, lima puluh persen masyarakat yang membayar zakatnya di Lembaga Amil Zakat (LAZ) tidak mengetahui bahwa pembayaran zakat dapat digunakan sebagai pengurang penghasilan kena pajak. Selain itu, pembayaran zakat cenderung tidak melalui pengelola zakat yang ditunjuk oleh pemerintah.

Zakat penghasilan dapat diakui sebagai pengurang penghasilan kena pajak ketika memenuhi beberapa persyaratan yang bersifat kumulatif dan dilaporkan dalam laporan pajak penghasilan tahunan. Persyaratan tersebut meliputi (1) zakat harus nyata-nyata dibayarkan oleh wajib pajak orang pribadi pemeluk Islam atau wajib pajak badan dalam negeri yang dimiliki oleh orang Islam, (2) zakat dibayarkan kepada badan amil zakat atau lembaga amil zakat yang dibentuk atau disahkan oleh pemerintah, serta (3) zakat yang dibayar adalah zakat yang terkait dengan penghasilan yang menjadi obyek pajak (Undang-Undang Nomor 23 Tahun 2011).

Menurut Spicer dan Lundset (1976) dalam Razman (2005), jika pengetahuan dan pemahaman dalam perpajakan rendah maka kepatuhan wajib pajak terhadap peraturan perpajakan yang berlaku juga rendah. Tingkat pemahaman wajib pajak pada peraturan perpajakan berpengaruh terhadap kepatuhan wajib pajak. Sehingga, semakin tinggi tingkat pengetahuan dan 
pemahaman wajib pajak pada peraturan perpajakan, maka semakin tinggi kemungkinan wajib pajak untuk mematuhi peraturan perpajakan.

Menurut (Deni, 2018), penerimaan kantor wilayah direktorat jenderal pajak Daerah Istimewa Yogyakarta menyatakan bahwa penerimaan KPP Pratama Bantul adalah yang paling tinggi yaitu 85, 27 persen. Sedangkan, KPP Pratama Sleman (82,08 persen), KPP Pratama Kota Yogyakarta (80,87 persen), KPP Pratama Wates $(75,47$ persen), serta KPP Pratama Wonosari (67,22 persen). Penerimaan dari masing-masing KPP Pratama di Daerah Istimewa Yogyakarta disajikan pada gambar 1.

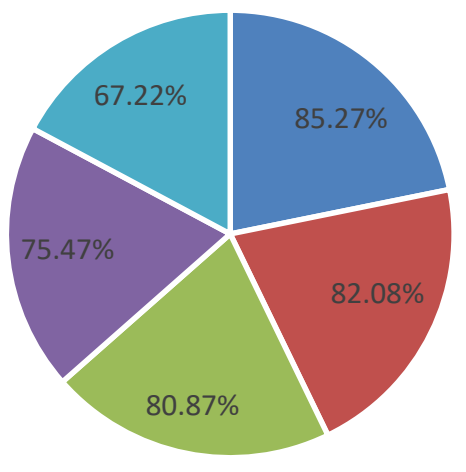

- Bantul - Sleman - Kota Yogyakarta - Wates - Wonosari

Gambar 1. Penerimaan KPP Pratama di Daerah Istimewa Yogyakarta Sumber: (Deni, 2018)

Menurut data yang disajikan pada (LAMINDUK, 2019), penduduk di kabupaten Bantul yang beragama Islam pada tahun 2018 semester II mencapai 95,9 persen atau 901.433 pendidik dari total jumlah penduduk 939.718. Serta 4,1 persen penduduk Bantul beragama Kristen, Katholik, Hindu, Budha, dan Konghuchu.

Penelitian yang terkait dengan zakat dan pajak sepengetahuan peneliti belum banyak dilakukan. Sehingga, hal ini yang menjadi dasar peneliti tertarik untuk melakukan penelitian mengenai pengetahuan tentang pajak sebagai pengurang penghasilan tidak kena pajak dan tingkat pendapat terhadap kepatuhan wajib pajak Muslim. Hal ini karena mayoritas penduduk Indonesia beragama Islam, sehingga wajib pajak pun kebanyakan pemeluk agama Islam.

\section{TINJAUAN PUSTAKA DAN PENGEMBANGAN HIPOTESIS Pengetahuan Pajak}

Hakikat dari pengetahuan merupakan sekumpulan yang diketahui oleh individu mengenai objek termasuk didalamnya adalah ilmu (Sumantri, 1993). Sehingga, kesediaan membayar zakat adalah sebuah kewajiban bagi setiap Muslim. Oleh karena itu, setiap Muslim perlu mengetahui hal yang terkait dengan zakat.

Menurut (Undang-Undang Nomor 23 Tahun 2011), pajak didefinisikan sebagai harta yang wajib dikeluarkan oleh seorang muslim maupun badan usaha untuk diberikan kepada yang berhak menerimanya sesuai dengan syariat Islam. 
Sedangkan, Menurut (Ikatan Akuntan Indonesia, 2008), zakat merupakan harta yang wajib dikeluarkan oleh muzakki sesuai dengan ketentuan Syari'ah untuk diberikan kepada yang berhak menerimanya (mustahiq).

Harta kekayaan yang wajib dizakati harus memenuhi syarat halal, milik penuh, berkembang, cukup hisab, cukup haul, bebas dari hutang, dan lebih dari kebutuhan pokok. Halal berarti bahwa harta tersebut harus didapatkan dengan cara yang baik serta halal (sesuai dengan tuntunan syariah). Milik penuh berarti bahwa kepemilikan berupa hak untuk penyimpanan, pemakaian, pengelolaan yang diberikan Allah SWT kepada manusia dan didalamnya tidak ada hak orang lain. Berkembang berarti harta tersebut bertambah. Cukup nisab berarti jumlah minimal yang menyebabkan harta terkenan kewajiban zakat. Cukup haul berarti jangka waktu kepemilikan sudah melampaui 12 bulan. Bebas dari hutang berarti bahwa harta yang dikeluarkan bebas dari hutang. Serta, lebih dari kebutuhan pokok adalah lebih dari kebutuhan sehari-hari (Nurhayarti \& Wasilah, 2015).

Menurut Ali (2007), dalam konsep perpajakan wajib pajak menjadi subjek pajak dalam pelaksanaan perpajakan. Pengetahuan dan pemahaman peraturan perpajakan merupakan proses dimana wajib pajak mengetahui tentang perpajakan serta mengaplikasikan pengetahuan yang dimiliki untuk membayar pajak. Oleh karena itu, pada penelitian ini yang dimaksud dengan pengetahuan zakat adalah pemahaman mengenai konsep zakat secara umum.

\section{Pajak Penghasilan}

Pajak penghasilan adalah salah satu jenis pajak pusat. Objek pajak penghasilan adalah penghasilan dikenakan pada wajib pajak yang sudah memenuhi syarat subjektif dan syarat objektif. Menurut (Undang-undang Nomor 36 Tahun 2008), pengenaan penghasilan pada subjek pajak berkenaan dengan penghasilan yang diterima atau diperolehnya dalam tahun pajak. Subjek pajak tersebut dikenai pajak apabila menerima atau memperoleh penghasilan, dan disebut sebagai wajib pajak. Wajib pajak dikenai pajak atas penghasilan yang diterima atau diperoleh selama satu tahun pajak atau dapat dikenai pajak untuk penghasilan dalam bagian tahun pajak apabila kewajiban pajak subjektifnya dimulai atau berakhir dalam tahun pajak (tahun kalender). Akan tetapi, wajib pajak dapat menggunakan tahun buku yang tidak sama dengan tahun kalender, sepanjang tahun buku tersebut meliputi jangka waktu dua belas bulan.

Subjek pajak penghasilan salah satunya adalah subjek pajak orang pribadi, yaitu orang pribadi yang bertempat tinggal di Indonesia, orang pribadi yang bertempat tinggal di Indonesia lebih dari 183 hari dalam jangka waktu 12 bulan, atau orang pribadi yang dalam tahun pajak berada di Indonesia dan mempunyai niat untuk tinggal di Indonesia. Penghasilan kena pajak bagi wajib pajak dalam negeri dan bentuk usaha tetap didasarkan pada penghasilan bruto dikurangi biaya untuk mendapatkan, menagih, dan memelihara penghasilan (Undang-undang Nomor 36 Tahun 2008).

\section{Pendapatan}

Pendapatan merupakan tambahan harta yang diperoleh dari sumber yang diketahui dan bersifat tetap. Sumber pendapatan dapat bersifat material (seperti tanah) atau non material (seperti pekerjaan), maupun bisa dari keduannya. Oleh karena itu, pendapatan terbagi atas penghasilan, gaji/upah dan keuntungan (Satrio \& Siswanto, 2016). 


\section{Kepatuhan}

Kepatuhan merupakan motivasi seseorang, kelompok atau organisasi untuk berbuat sesuai dengan aturan yang ditetapkan. Aturan pajak yang berlaku adalah undang-undang perpajakan. Sehingga, kepatuhan pajak merupakan kepatuhan wajib pajak pada undang-undang perpajakan (Gibson, 1991) dalam (Jatmiko, 2006). Kepatuhan wajib pajak merupakan pemenuhan kewajiban perpajakan yang dilakukan oleh pembayar pajak dalam rangka memberikan kontribusi bagi pembangunan Negara serta dalam rangka pemenuhan kewajiban yang dilakukan secara sukarela. Kepatuhan wajib pajak menjadi salah satu aspek penting. Hal ini karena sistem perpajakan di Indonesia menganut self assessment system. Sistem ini memberikan kepercayaan kepada wajib pajak dalam menghitung, membayar, dan melaporkan kewajibannya (Tiraada, 2013); (Irmawati \& Hidayatulloh, 2019).

Dari uraian latar dan kajian teori, maka rerangka penelitian ini adalah sebagai berikut:

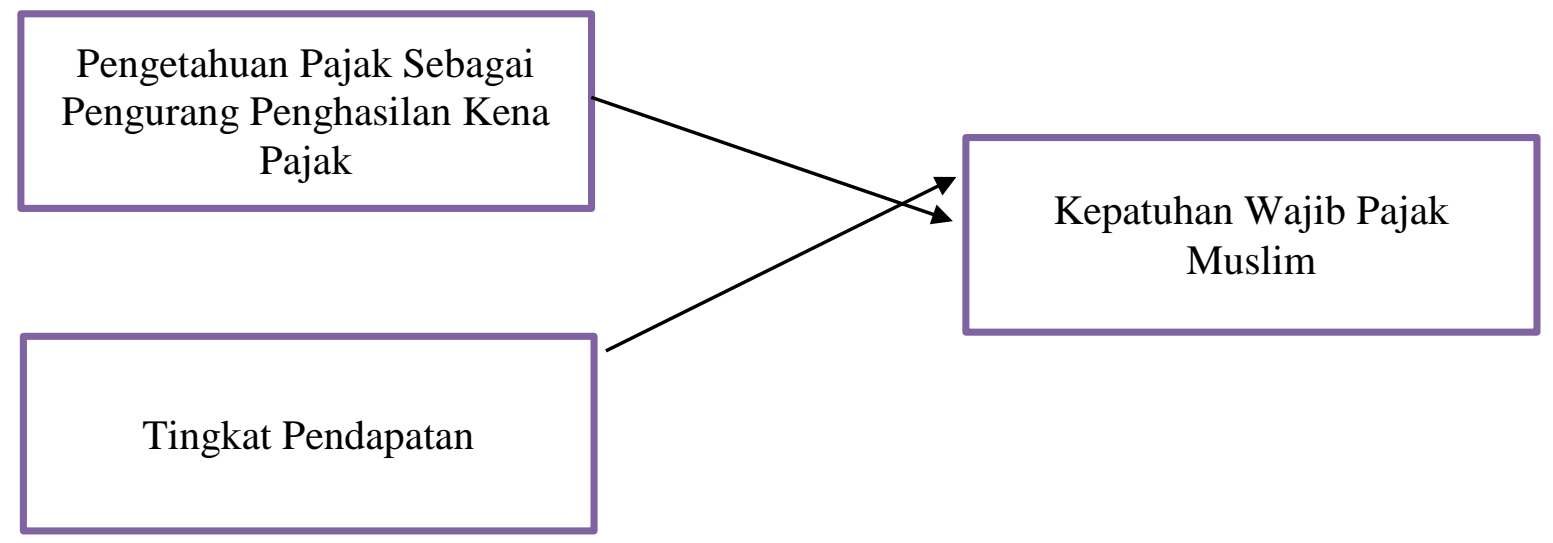

Gambar 2. Rerangka Penelitian

\section{Pengaruh Pengetahuan Pajak Sebagai Pengurang Penghasilan Tidak Kena Pajak Terhadap Kepatuhan Wajib Pajak Muslim}

Pembayaran zakat dan pajak sama-sama bernilai ibadah. Kewajiban zakat jelas berdasarkan pada Al-Qur'an dan Hadist yang kemudiaan dibentuk undangundang nomor 23 Tahun 2011 mengenai pengelolaan zakat. Sedangkan, kewajiban pajak didasarkan pada ijtihad Ulil Amri (pemerintah) yang dituangkan dalam peraturan undang-undang. Agama pun memerintakan untuk taat kepada Ulil Amri. Oleh karena itu, melaksanakan pajak pada hakekatnya juga melaksanakan perintah agama dan sebagai realisasi ketaatan kepada Ulil Amri (Sarbini, 2013).

Zakat yang dibayarkan kepada Badan Amil Zakat (BAZ) atau Lembaga Amil Zakat (LAZ) dapat dikurangkan pada laba atau pendapatan sisa kena pajak dari wajib pajak yang bersangkutan. Hal tersebut menjelaskan bahwa zakat atas penghasilan yang nyata-nyata dibayarkan secara resmi oleh wajib orang pribadi yang memeluk agama Islam atau wajib pajak dalam negeri yang dimiliki kaum muslimin dapat dikurangkan atas penghasilan kena pajak (Undang-Undang Nomor 23 Tahun 2011). Pernyataan ini didukung oleh hasil penelitian Fitranoska (2006) yang menyatakan bahwa terdapat hubungan yang kuat antara zakat sebagai pengurang penghasilan kena pajak dengan pemenuhan kewajiban pajak. Bahkan, pengetahuan zakat sebagai pengurang penghasilan kena pajak memberikan 
kontribusi 59,2 persen pada kepatuhan wajib pajak orang pribadi. Oleh karena itu, dari uraian sebelumnya maka hipotesis pertama $\left(\mathrm{H}_{1}\right)$ penelitian ini adalah sebagai berikut:

$\mathrm{H}_{1}$ : Pengetahuan zakat sebagai pengurang penghasilan kena pajak berpengaruh terhadap kepatuhan wajib pajak Muslim

\section{Pengaruh Tingkat Pendapatan Terhadap Kepatuhan Wajib Pajak Muslim}

Menurut Satrio \& Siswanto (2016), pendapatan didefinisikan sebagai tambahan harta yang diperoleh dari sumber yang diketahui serta bersifat tetap. Pendapatan dapat bersifat material (seperti tanah) atau non material (seperti pekerjaan) maupun kombinasi keduanya. Menurut Alm, Bloomquist, \& Mckee (2015), jumlah penghasilan dan kepatuhan pajak memiliki hubungan yang positif. Hal ini karena tingkat penghasilan yang diterima oleh wajib pajak mengakibatkan jumlah penghasilan yang dilaporkan lebih tinggi. Menurut Chau \& Leung (2009), wajib pajak yang memiliki jumlah penghasilan yang lebih rendah memiliki kecenderungan kepatuhan yang rendah pula. Hal ini dapat dilihat dari pelaporan penghasilan yang lebih rendah dari keadaanya yang sebenarnya. Pernyataan ini didukung oleh Torgler \& Schneider (2006), tingkat penghasilan yang tinggi mengakibatkan kepatuhan yang tinggi juga. Oleh karena itu, dari uraian sebelumnya maka hipotesis kedua $\left(\mathrm{H}_{2}\right)$ penelitian ini adalah sebagai berikut:

$\mathrm{H}_{2}$ : Tingkat pendapatan berpengaruh terhadap kepatuhan wajib pajak muslim

\section{METODE PENELITIAN}

Populasi dalam penelitian ini adalah wajib pajak di kabupaten Bantul. Teknik pengambilan sampel dalam penelitian ini menggunakan purposive sampling, dengan kriteria (1) wajib pajak Muslim di kabupaten Bantul, (2) wajib pajak yang memiliki Nomor Pokok Wajib Pajak (NPWP). Serta (3) wajib pajak yang melakukan kegiatan usaha atau melaksanakan pekerjaan bebas. Sehingga, sampel dalam penelitian ini adalah wajib pajak Muslim yang memiliki NPWP serta melakukan kegiatan usaha atau melaksanakan pekerjaan bebas. Pengumpulan data dalam penelitian ini menggunakan kuesioner yang disebarkan secara langsung kepada responden yang memenuhi kriteria.

Variabel dalam penelitian ini terdiri dari variabel independen (pengetahuan pajak sebagai pengurang penghasilan kena pajak, dan tingkat pendapatan). Sedangkan, variabel dependen dalam penelitian ini yaitu kepatuhan wajib pajak Muslim. Definisi dan pengukuran masing-masing variabel disajikan pada tabel 1 . Teknik analisis data dalam penelitian ini menggunakan analisis regresi linear berganda. 
Tabel 1

Ringkasan Definisi Variabel dan Skala Pengukuran Varibel

\begin{tabular}{|c|c|c|c|c|}
\hline Variabel & Definisi & Referensi & $\begin{array}{l}\text { Skala } \\
\text { Pengukuran }\end{array}$ & Referensi \\
\hline $\begin{array}{l}\text { Pengetahuan } \\
\text { zakat sebagai } \\
\text { pengurang } \\
\text { penghasilan } \\
\text { kena pajak }\end{array}$ & $\begin{array}{lr}\text { Harta yang } & \text { wajib } \\
\text { dikeluarkan } & \text { seorang } \\
\text { muslim atau badan } & \text { badak } \\
\text { usaha untuk diberikan } \\
\text { kepada yang berhak } \\
\text { menerimanya sesuai } \\
\text { dengan syariat Islam. } \\
\text { Zakat yang dibayarkan } \\
\text { melalui Lembaga Amil } \\
\text { Zakat (LAZ) dapat } \\
\text { menjadi pengurang dari } \\
\text { penghasilan kena pajak }\end{array}$ & $\begin{array}{l}\text { (Undang- } \\
\text { Undang } \\
\text { Nomor } 23 \\
\text { Tahun } \\
\text { 2011). }\end{array}$ & $\begin{array}{l}\text { Lima item } \\
\text { pertanyaan } \\
\text { yang } \\
\text { menggunakan } \\
\text { skala likert } \\
\text { lima point }\end{array}$ & $\begin{array}{l}\text { (Ghaffari, } \\
\text { 2017) }\end{array}$ \\
\hline $\begin{array}{l}\text { Tingkat } \\
\text { pendapatan }\end{array}$ & $\begin{array}{l}\text { Tambahan harta yang } \\
\text { diperoleh dari sumber } \\
\text { yang diketahui dan } \\
\text { bersifat tetap. Sumber } \\
\text { pendapatan bersifat } \\
\text { material, non material, } \\
\text { maupun keduannya }\end{array}$ & $\begin{array}{l}\text { (Satrio \& } \\
\text { Siswanto, } \\
\text { 2016) }\end{array}$ & $\begin{array}{l}\text { Empat item } \\
\text { pertanyaan } \\
\text { yang } \\
\text { menggunakan } \\
\text { skala likert } \\
\text { lima point }\end{array}$ & $\begin{array}{l}\text { (Ernawati, } \\
\text { 2014) }\end{array}$ \\
\hline $\begin{array}{l}\text { Kepatuhan } \\
\text { wajib pajak } \\
\text { muslim }\end{array}$ & $\begin{array}{lr}\text { Motivasi } & \text { seseorang, } \\
\text { kelompok, } & \text { atau } \\
\text { organisasi } & \text { untuk } \\
\text { berbuat sesuai dengan } & \text { deng } \\
\text { peraturan yang telah } \\
\text { ditetapkan. } \\
\text { pajak yang berlaku } \\
\text { adalah undang-undang } \\
\text { perpajakan. Sehingga, } \\
\text { kepatuhan rajan } \\
\text { merupakan kepatuhan } \\
\text { wajib pajak pada } \\
\text { undang-undang } \\
\text { perpajakan }\end{array}$ & $\begin{array}{l}\text { (Gibson, } \\
\text { 1991) } \\
\text { dalam } \\
\text { (Jatmiko, } \\
\text { 2006) }\end{array}$ & $\begin{array}{l}\text { Enam item } \\
\text { pertanyaan } \\
\text { yang } \\
\text { menggunakan } \\
\text { skala likert } \\
\text { lima point }\end{array}$ & $\begin{array}{l}\text { (Alfiah, } \\
\text { 2014) }\end{array}$ \\
\hline
\end{tabular}

\section{HASIL PENGUJIAN HIPOTESIS}

Responden dalam penelitian berjumlah 36 responden. Responden dalam penelitian ini didominasi oleh responden berjenis kelamin laki-laki (22 responden), sedangkan responden berjenis kelamin perempuan berjumlah 14 responden. Usia responden didominasi oleh usia 20-30 tahun (17 responden). Responden yang memiliki usaia 31-40 tahun (lima responden), dan 14 responden berusia diatas 40 tahun. Pendidikan responden didominasi oleh tingkat pendidikan sarjana (22 responden). Responden yang memiliki tingkat pendidikan Diploma (satu responden), SMA (sembilan responden), SMP (dua responden), dan SD (dua 
Responden). Tingkat pendapatan responden didominasi oleh Rp5.000.000Rp10.000.000 (25 responden). Sedangkan, responden yang memiliki tingkat pendapatan Rp lebih besar 10.000.0001-20.000.000 (tujuh responden), dan responden yang memiliki pendapatan lebih besar dari Rp20.000.000 berjumlah empat responden. Jenis pekerjaan responden didominasi oleh wiraswasta (15 responden). Lebih rinci mengenai jenis pekerjaan responden disajikan pada gambar 3.

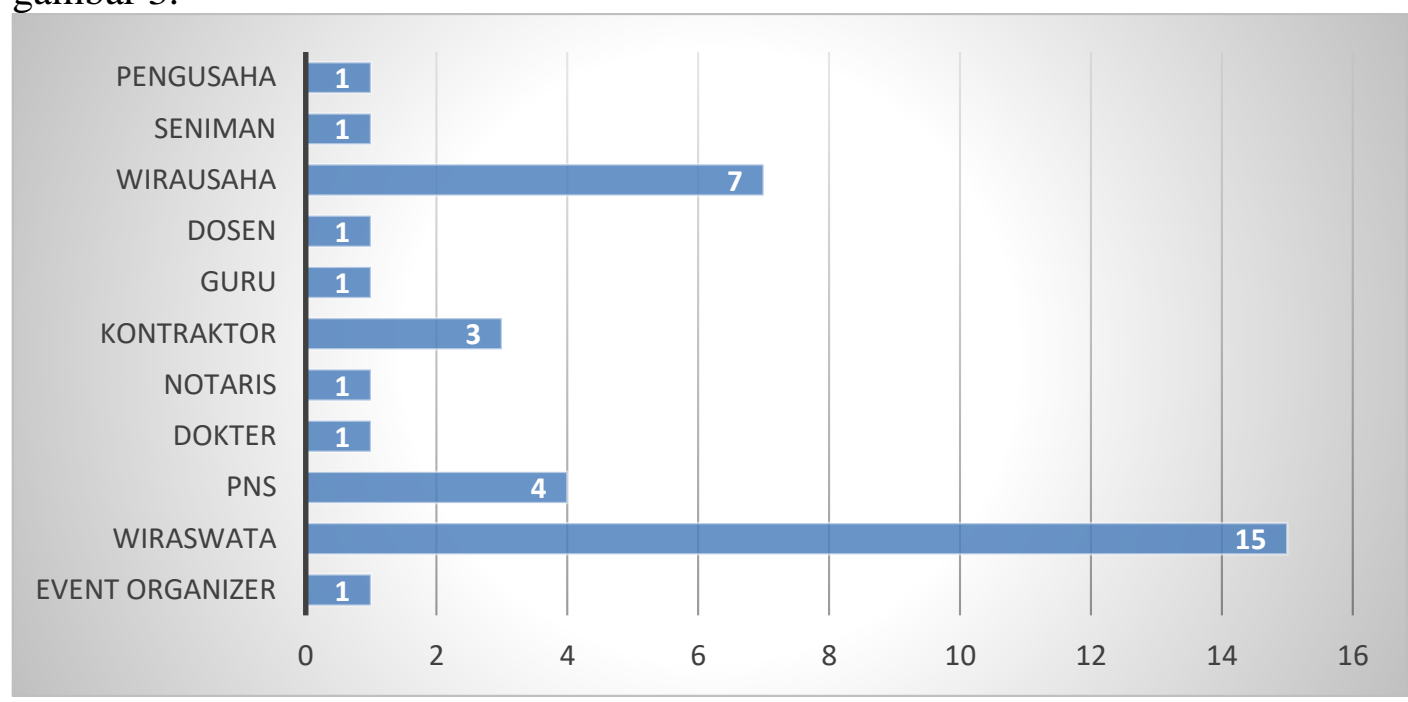

Gambar 3. Jenis Pekerjaan Responden

Sumber: data primer, diolah (2019)

Teknik analisis data dalam penelitian ini menggunakan analisis regresi linear berganda dengan bantuan alat SPSS. Sebelum melakukan pengujian hipotesis, penelitian ini melakukan pengujian kualitas data (uji validitas dan uji reliabilitas) serta uji asumsi klasik (uji normalitas, uji multikolineritas, dan uji heteroskesdasitas). Dari hasil uji kualitas data dan uji asumsi klasik, penelitian ini memenuhi kedua pengujian tersebut. Hasil pengujian hipotesis disajikan pada tabel 2.

Tabel 2.

Hasil Pengujian Hipotesis

\begin{tabular}{lllll}
\hline \multicolumn{1}{c}{ Variabel } & Koefisien & Signifikansi & Alpha & \multicolumn{1}{c}{ Keputusan } \\
\hline $\begin{array}{l}\text { Pengetahuan Zakat } \\
\text { Sebagai pengurang }\end{array}$ & 0,159 & 0,178 & 0,05 & $\mathrm{H}_{1}$ tidak terdukung \\
PKP & & & & \\
\hline $\begin{array}{l}\text { Tingkat } \\
\text { Pendapatan }\end{array}$ & 0,224 & 0,001 & 0,05 & $\mathrm{H}_{2}$ terdukung \\
\hline Konstanta & $=7,535$ & & \\
Variabel Dependen & $=$ Kepatuhan WP Muslim & & \\
$\begin{array}{ll}\text { Adjusted } R \text { Square } \\
\text { F Statistik }\end{array}$ & $=0,277$ & & & \\
Signifikansi & $=7,701$ & & & \\
& $=0,002$ & &
\end{tabular}

Sumber: data primer, diolah (2019) 
Tabel 2 menunjukan bahwa penelitian ini memiliki nilai adjusted $R$ Square sebesar 0,277. Hal ini berarti bahwa variabel pengetahuan zakat sebagai pengurang penghasilan kena pajak dan tingkat pendapatan dapat menjelaskan variabel kepatuhan wajib pajak muslim sebesar 27,7 persen. Sedangkan, 72,3 persen variabel kepatuhan wajib pajak muslim dijelaskan oleh variabel lain di luar model. Uji F menunjukan bahwa penelitian ini memiliki nilai signifikasi 0,002 yang lebih kecil dibandingkan dengan 0,05. Oleh karena itu, minimal ada satu variabel independen (pengetahuan zakat sebagai pengurang penghasilan kena pajak dan tingkat pendapatan) yang berpengaruh terhadap kepatuhan wajib pajak Muslim.

Kepatuhan wajib pajak Muslim tidak dipengaruhi oleh pengetahuan zakat sebagai pengurang penghasilan kena pajak. Hal ini ditunjukan dengan nilai signifikasi $(0,178)$ yang lebih besar dibandingkan dengan 0,05 . Atau dengan kata lain, hipotesis pertama $\left(\mathrm{H}_{1}\right)$ penelitian ini tidak terdukung. Hal ini berarti tinggi rendahnya pengetahuan pajak sebagai pengurang penghasilan kena pajak bukanlah menjadi pertimbangan atau pengaruh bagi wajib pajak Muslim untuk membayar pajaknya. Bagi wajib pajak muslim melaksanakan pembayaran pajak merupakan suatu kewajiban bagi setiap muslim dan membayar zakat adalah sebuah ibadah (Sarbini, 2013). Hal tersebut dibuktikan dengan banyaknya frekuensi responden yang menjawab tidak setuju pada item pertanyaan "zakat dianggap sebagai biaya”. Ketidakterdukungan $\mathrm{H}_{1}$ mungkin disebabkan karena (1) tidak semua orang Muslim menyalurkan zakatnya pada lembaga amil zakat yang dibentuk oleh pemerintah, (2) responden tidak mengetahui bahwa penyaluran zakat pada lembaga amil zakat yang dibentuk oleh pemerintah dapat mengurangi penghasilan kena pajak. Pernyataan ini didukung oleh Muktiyanto \& Hendrian (2008), lebih dari lima puluh persen masyarakat yang membayarkan zakatnya di lembaga amil zakat tidak mengetahui bahwa pembayaran zakat dapat digunakan sebagai pengurang penghasilan kena pajak, dan pembayaran zakat cenderung tidak melalui pengelola zakat yang ditunjuk oleh pemerintah. Kepatuhan wajib pajak Muslim dipengaruhi oleh tingkat pendapatan. Hal ini ditunjukan dengan nilai signifikasi $(0,001)$ yang lebih kecil dibandingkan dengan 0,05 . Atau dengan kata lain, hipotesis kedua $\left(\mathrm{H}_{2}\right)$ penelitian ini terdukung. Oleh karena itu, wajib pajak yang memiliki jumlah penghasilan yang lebih rendah memiliki kepatuhan yang cenderung rendah. Begitu sebaliknya, wajib pajak yang memiliki tingkat penghasilan yang tinggi memiliki kecenrungan untuk bersikap lebih patuh. Hasil ini mendukung hasil penelitian sebelumnya Ghozali (2017); Alm et al. (2015); Ernawati (2014); Chau \& Leung (2009); Torgler \& Schneider (2006) yang menyatakan bahwa tingkat pendapatan berpengaruh terhadap kepatuhan wajib pajak.

\section{KESIMPULAN, KETERBATASAN DAN SARAN}

Kepatuhan wajib pajak Muslim dipengaruhi oleh tingkat pendapatan. Hal ini berarti wajib pajak yang memiliki jumlah penghasilan yang lebih rendah memiliki kecenderungan untuk bersikap tidak patuh, dan sebaliknya. Wajib pajak yang memiliki tingkat penghasilan yang tinggi memiliki kecenderungan untuk bersikap patuh. Sehingga, dari hasil penelitian ini diharapkan pemerintah dalam hal ini direktorat jenderal pajak untuk lebih mengawasi wajib pajak yang memiliki penghasilan rendah. Akan tetapi, kepatuhan wajib pajak Muslim tidak dipengaruhi oleh pengetahuan zakat sebagai pengurang penghasilan kena pajak. Hal ini karena 
wajib pajak Muslim tidak selalu membayarkan pajaknya pada lembaga amil zakat yang ditunjuk oleh pemerintah. Wajib pajak Muslim dapat menyalurkan zakatnya pada masyarakat sekitar yang memang masyarakat tersebut adalah individu yang berhak menerima zakat.

Responden dalam penelitian ini berjumlah 36 responden. Hal ini disebakan karena beberapa responden tidak berkenan untuk mengisi kuesioner. Sehingga, penelitian selanjutnya dapat menambahkan jumlah responden.

\section{REFERENCES}

Alfiah, I. (2014). Kesadaran Perpajakan, Sanksi Perpajakan, Sikap Fiskus,Lingkunga Pajak, Pengetahuan Perpajakan Pajak,Persepsi Efektifitas Sistem Perpajakan, Kemauan Membayar Pajak Terhadap Kepatuhan Wajib pajak Orang Pribadi di DPPKAD Grobogan-Purwodadi. Universitas Muria Kudus.

Ali, Z. (2007). Pendidikan Agama Islam. Palu: Bumi Aksara.

Alm, J., Bloomquist, K. M., \& Mckee, M. (2015). On the external validity of laboratory tax compliance experiments. Economic Inquiry, 53(2), 11701186. https://doi.org/10.1111/ecin.12196

Chau, G., \& Leung, P. (2009). A Critical Review of Fischer's Tax Compilance Model: A Research Synthesis. Journal of Accounting and Taxaction, 1(2), $34-40$.

Deni. (2018). 36.763 Jadi Wajib Pajak Baru di DIY. Retrieved from https://www.starjogja.com/2018/12/17/wajib-pajak/.

Ernawati. (2014). Pengaruh Tingkat Pendidikan, Pendapatan, dan Kualitas Pelayanan Fiskus Terhadap Kepatuhan Wajib Pajak. Universitas Hasannudin Makasar.

Fitranoska, E. R. (2006). Pengaruh Zakat Sebagai Pengurang Penghasilan Kena Pajak Terhadap Kepatuhan Wajib Pajak Orang Pribadi: Pada KPP Pratama Jakarta Tanah Abang. Universitas Indonesia.

Ghaffari, M. A. (2017). Respon Wajib Pajak Terhadap Zakat Sebagai Pengurang Penghasilan Kena Pajak (Studi Pada Kantor Pelayanan Pajak Pratama Jakarta Kebayoran Bari Tiga). UIN Syarif Hidayatullah Jakarta.

Ghozali, E. E. (2017). Pengaruh Tingkat Pendapatan, Tarif Pajak, Denda Pajak, dan Probabilitas Pemeriksaan Pajak Terhadap Kepatuhan Pajak. Diponegoro Journal Of Accounting, 6(3).

Ikatan Akuntan Indonesia. (2008). PSAK No 109.

Irmawati, J., \& Hidayatulloh, A. (2019). Determinan Kepatuhan Wajib Pajak UMKM di Kota Yogyakarta. Jurnal Sistem Informasi, Keuangan, Auditing Dan Perpajakan, 3(2), 112-121.

Jatmiko, A. N. (2006). Pengaruh Sikap Wajib Pajak Pada Pelaksanaan Sanksi Denda, Pelayanan Fiskus, dan Kesadaran Perpajakan Terhadap Kepatuhan Wajib Pajak (Universitas Diponogoro). Retrieved from http://eprints.undip.ac.id/15261/1/Agus_Nugroho_Jatmiko.pdf. 02November 2017

LAMINDUK. (2019). Jumlah Penduduk Menurut Agama 2019. Retrieved from https://kependudukan.jogjaprov.go.id/olah.php?module=statistik\&periode $=1$ $1 \&$ jnisdata $=$ penduduk \&berdasarkan=agama $\&$ prop $=34 \& \mathrm{kab}=2$. 
Mardiasmo. (2016). Perpajakan (2016th ed.). CV Andi.

Muktiyanto, \& Hendrian. (2008). Zakat Sebagai Pengurang Pajak. Jurnal Organisasi Dan Manajemen.

Nurhayarti, S., \& Wasilah. (2015). Akuntansi Syariah di Indonesia. Jakarta: Salemba Empat.

Peraturan Pemerintah Nomor 101/PMK Tahun 2016 Tentang Penyesuaian Besarnya Penghasilan Tidak kena Pajak.

Razman, A. A. L. (2005). Tax Literacy Rate Among Tax Payers: Evidence From Malaysia. Jurnal Akuntansi Dan Auditing Indonesia, 9(1).

Resmi, S. (2014). Perpajakan: Teori dan kasus. Jakarta: Salemba Empat.

Sarbini, A. (2013). Zakat dan Pajak. Jurnal Syariah, 2(2).

Satrio, E., \& Siswanto, D. (2016). Analisis Faktor Kepercayaan, Pendapatan Pada Minat Muzzaki Untuk Membayar Zakat Penghasilan Pada Amil Zakat. Universitas Indonesia.

Sumantri, J. S. (1993). Filsafat Ilmu: Sebuah Pengantar Populer. Jakarta: Pustaka Sinar Harapan.

Tiraada, T. A. (2013). Kesadaran Perpajakan, Sanksi Pajak, Sikap Fiskus Terhadap Kepatuhan WPOP di Kabupaten Minahasa Selatan. Jurnal EMBA, 1(3).

Torgler, B., \& Schneider, F. (2006). What Shapes Attitudes Toward Paying Tax? Evidence from Multicultural European Countries. Social Science Quarterly, $88(2), 443-465$.

Undang-undang Nomor 28 Tahun 2007 Tentang Ketentuan Umum dan Tata Cara Perpajakan

Undang-undang Nomor 36 Tahun 2008 Tentang Pajak Penghasilan

Undang-Undang Nomor 23 Tahun 2011 Tentang Pengelolaan Zakat.

Yusuf, M., \& Ismail, T. (2017). Pengaruh Pengetahuan Pajak, Pengetahuan Zakat dan Sikap terhadap Kepatuhan Wajib Pajak Muslim. Universitas Mercuana Jakarta. 